\title{
Enhancement with inducers of lacasse production by some strains and application of enzyme to dechlorination of 2,4,5-trichlorophenol
}

\author{
Serap Gedikli ${ }^{1} \cdot$ Pinar Aytar $^{1} \cdot$ Arzu Ünal $^{2} \cdot$ Mustafa Yamaç$^{3} \cdot$ Ahmet Çabuk $^{3} \varangle \cdot$ Nazif Kolankaya $^{4}$ \\ 1 Graduate School of Natural and Applied Sciences, Eskişehir Osmangazi University, Eskişehir, Turkey \\ 2 Ministry of Agriculture and Rural Affairs, General Directorate of Agricultural Research, Ankara, Turkey \\ 3 Department of Biology, Faculty of Arts and Science, Eskişehir Osmangazi University, Eskişehir, Turkey \\ 4 Department of Biology, Division of Biotechnology, Faculty of Science, Hacettepe University, Beytepe, Ankara, Turkey \\ $\triangle$ Corresponding author: acabuk@ogu.edu.tr \\ Received May 7, 2010 / Accepted September 22, 2010 \\ Published online: November 15, 2010 \\ (C) 2010 by Pontificia Universidad Católica de Valparaíso, Chile
}

\begin{abstract}
Lacasse is one of the extracellular enzymes excreted from white and brown rot fungi, which is involved in ligninolysis. In the present study, the effects of the addition of lacasse inducers to the medium on enhancement of enzyme production under conditions of submerged fermentation were researched. At first, a culture medium was selected suitable for lacasse production. To increase the production of lacasse using different inducers and to examine the ability of dechlorination, this article focuses on screen lacasse activity of 21 basidiomycetes isolates grown in five culture media. All inducers evaluated influenced lacasse activity positively except for gallic acid, mannitol, and malt extract for studied isolates. Our findings showed that lacasse activity of Trametes versicolor ATCC (200801) when it was induced with wheat bran reached up to $29.08 \mathrm{U} \mathrm{ml}^{-1}$ and was examined the ability of dechlorination of 2,4,5-trichlorophenol (2,4,5-TCP). The parameters including $\mathrm{pH}$, initial substrate concentration, amount of enzyme, period of reaction, and temperature were tested for dechlorination process. Correlation between oxygen consumption and dechlorination processes under the determined optimum conditions was analyzed. Toxicity of 2,4,5-TCP before and after enzymatic treatment was evaluated by Microtox test. The results demonstrated that toxicity of intermediates formed 2,4,5-TCP did not change.
\end{abstract}

Keywords: 2,4,5-trichlorophenol, basidiomycetes, dechlorination, inducer, lacasse

\section{INTRODUCTION}

Lacasse (benzenediol: oxygen oxidoreductase; E.C. 1.10.30.2) is a multi-copper containing protein using molecular oxygen to oxidize various phenolic and non-phenolic compounds by a radicalcatalyzed reaction mechanism (Thurston, 1994).

Lacasse is involved in lignin degradation and its low substrate specificity allows it to oxidize a wide range of compounds (Saparrat et al. 2002). Compounds involved in the natural degradation of lignin by white-rot fungi may be derived from oxidized lignin units or directly from fungal metabolism (Johannes and Majcherczyk, 2000). Besides, most of phenolic compounds are oxidized by lacasse, the mediators can diffuse far away from the mycelium to sites that are difficult to reach by the enzyme itself; therefore, these nonphenolic compounds have been oxidized through lacasse mediated system (Camarero et al. 2005; D'Acunzo et al. 2006).

This enzyme has been distributed among plants, insects, bacteria and fungi (Gianfreda et al. 1999). However, lacasse activity has mainly been demonstrated in basidiomycetes, ascomycetes and deuteromycetes (Sadhasivam et al. 2008). 


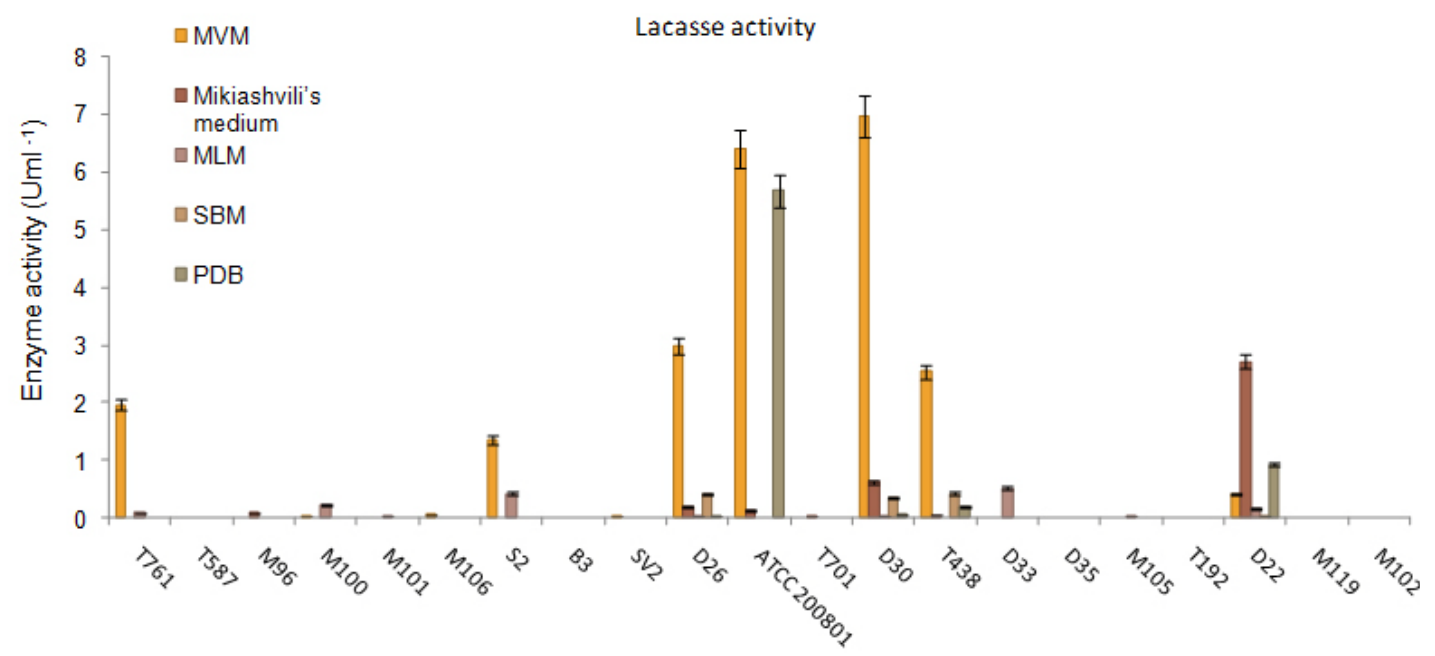

Studied isolates

Fig. 1 Laccase activities of isolates in different five media (see Materials and Methods for species names of fungal train).

White rot fungi belong to basidiomycetes are known to produce extracellular enzymes which are lacasse, manganese peroxidase, lignin peroxidase oxidizing phenolic and non-phenolic substrates. These fungi were grown on dead and/or live trees by degrading compounds such as cellulose and lignin. Enzymes excreted white rot fungi have recently taken attention (Ko et al. 2001).

Lacasse activity depends on the type of fungal strain used, growth conditions employed, the presence and the absence of inducers, incubation time, nature and composition of culture medium and genetic manipulation. Among these factors, corresponding to the presence of an inducer, its chemical structure, the amount added and the time of its addition influence lacasse production. Several compounds like phenolics strictly related to lignin or its derivatives induce this enzyme activity (Gianfreda et al. 1999). Generally, xylidine, copper sulphate, wheat bran, veratryl alcohol, ethanol, solid lignin were used for inducing lacasse activity (Rodriguez Couto et al. 2002; Papinutti et al. 2003; Cavallazi et al. 2005; Birhanli and Yesilada, 2006; Xavier et al. 2007). Besides, Flores and co-workers (Flores et al. 2010) used biological inducer and studied production of lacasses by Pleurotus ostreatus in submerged fermentation in co-culture with Trichoderma viride.

Lacasse has attracted much interest in recent years owing to its degradation ability to lignin related compounds as well as highly recalcitrant pollutants which makes it suitable for biotechnological and environmental applications. Such applications include the detoxification of industrial effluents, mostly from the paper and pulp, textile and petrochemical industries, being used as biosensor, a tool for medical diagnostics, and bioremediation agent to clean up herbicides, pesticides and certain explosives in soil and water (Rodriguez Couto and Toca, 2006). Lacasses are also used as catalysts for the manufacture of anti-cancer drugs (Unyayar et al. 2006).

White rot fungi degrade a wide variety of environmental pollutants such as chlorophenolic compounds, polycyclic aromatic hydrocarbons (PAHs), cyanide as well as desulphurizing coal (Sedarati et al. 2003; Baborová et al. 2006; Çabuk et al. 2006; Aytar et al. 2008).

Chlorinated phenols, recalcitrant compounds, are discharged from many chemical industries (Rubilar et al. 2008), especially pentachlorophenol, 2,6-dichlorophenol, 2,4,6-trichlorophenol, lindane, aldrin, 2,4dichlorophenol, dichlorodiphenyltrichloroethane (DDT) have a widespread environmental concern because of toxicity and persistence (Dercova et al. 2003; Furukawa, 2003; Sedarati et al. 2003; Kargi and Eker, 2004). 


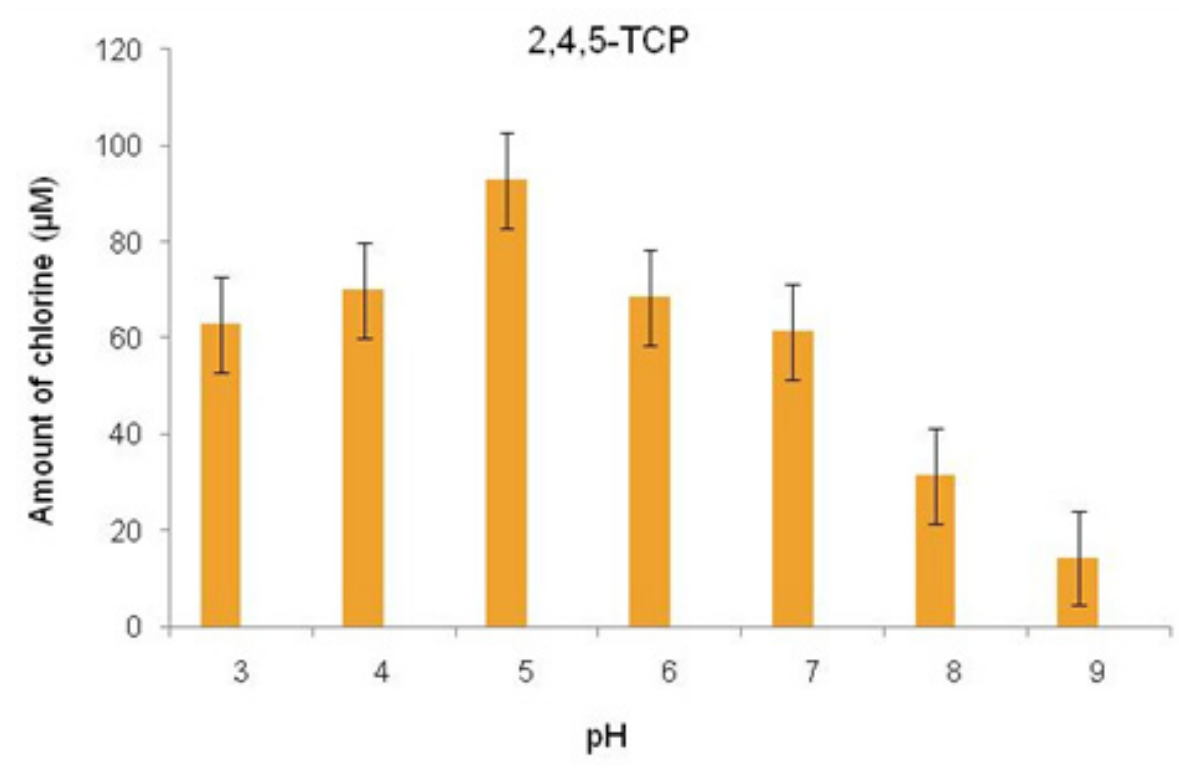

Fig. 2 Effect of pH on enzymatic dechlorination for 2,4,5-TCP (Substrate concentration: $150 \mu \mathrm{M}$; enzyme amount: $1 \mathrm{ml}$; incubation time: $30 \mathrm{~min}$; temperature $30^{\circ} \mathrm{C}$ ).

2,4,5-trichlorophenol (2,4,5-TCP) has been an intermediate in the manufacture of industrial and agricultural chemicals, such as the phenoxy acid herbicides 2,4,5-T (2,4,5-trichlorophenoxyacetic acid), [2-(2,4,5-trichlophenoxy) propionic acid, 2,4,5-TP] (Silvex), o,o-dimethyl-o-2,4,5-trichlorophenyl phosphorothionate (Ronnel), and sodium 2,4,5-trichlorophenate. Additionally, 2,4,5-TCP and its salts have been used to preserve to microorganisms for adhesive products, synthetic textiles, rubber, wood, paints, in the leather industry and in pulp and paper mills (Nichkova et al. 2002). 2,4,5-TCP is considered to have significant toxicological effects and potential carcinogenicity (IARC, 1986).

Toxicity, persistence and biodegradability of chlorophenols depend on the number and position of chlorine substituents on the phenolic ring. Chlorinated aromatics are known to be more recalcitrant than chlorinated aliphatics and biodegradability decreases with increasing number of chlorine groups (Kolankaya, 2006).

Biological treatment of chlorophenolics has been studied with different fungi including Phanerochaete chrysosporium, Candida maltosa, Pleurotus ostreatus, Lentinus edodes, Trametes versicolor, Pycnoporus cinnabarinus, Pleurotus sajor-caju (Cameron et al. 2000; Schultz et al. 2001; Rodriguez et al. 2004; Ünal and Kolankaya, 2004).

The aim of this study was to investigate the abilities of lacasse production of new white and brown rot fungi which had isolated from Eskişehir province. In this way, the production of lacasse of 21 microorganisms in five different media for up to 15 days of incubation period was explored. Then, the lacasse production of 5 microorganisms was evaluated in the presence of different inducers such as $\mathrm{CuSO}_{4}$, gallic acid, ammonium tartrate, malt extract, barley bran, wheat bran, Tween 80 , veratryl alcohol, mannitol, cone biomass of Pinus nigra by adding to potato dextrose broth (PDB) as the selected medium. Dechlorination of 2,4,5-TCP was done with the highest activity of lacasse obtained. The toxicity of this treated chlorophenolic compound was examined by means of the Microtox toxicity test.

\section{MATERIALS AND METHODS}

\section{Microorganisms and chemicals}

Formerly isolated from province of Eskişehir, Turkey and identified macrofungi Polyporus arcularius (T438), Schizophyllum commune (T701), Clavariadelphus truncatus (T192), Pleurotus eryngii (M102), 


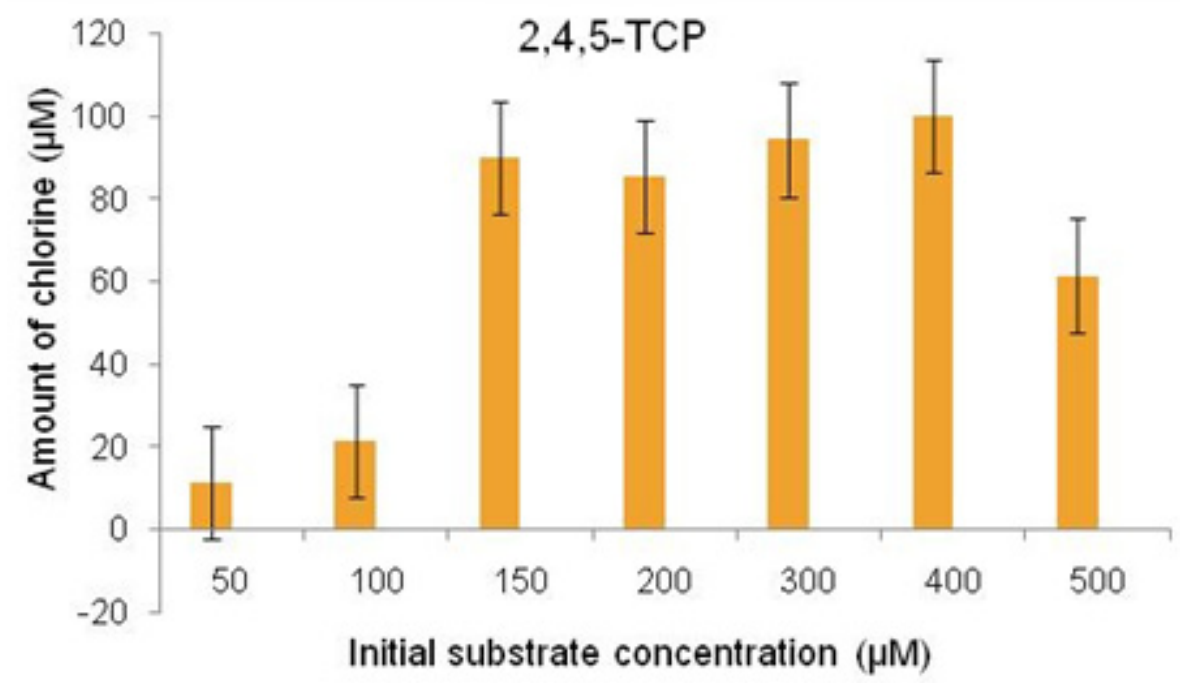

Fig. 3 Effect of initial substrate concentration on enzymatic dechlorination for 2,4,5-TCP (Enzyme amount: $1 \mathrm{ml}$; incubation time: $30 \mathrm{~min}$; temperature: $30^{\circ} \mathrm{C} ; \mathrm{pH}: 5$ ).

Ganoderma applanatum (M105), Trametes versicolor (D22), Cerrena unicolor (D30), Schizophyllum commune (D35), Ganoderma lucidum (D33), Pleurotus ostreatus (M119), Trametes hirsuta (T587), Polyporus arcularius (T761), Trametes versicolor (M96), Fomes fomentarius (M100), Antrodia serialis (M101), Inonotus hispidus (M106), Lenzites betulina (S2), Stereum hirsutum (B3), Tapinella panuoides (SV2), Lentinus strigosus (D26) were maintained in potato dextrose agar (PDA) at $+4^{\circ} \mathrm{C}$ in Fungal Culture Collection of Biology Department, Eskisehir Osmangazi University. Trametes versicolor ATCC (200801) was provided from ATCC.

\section{Culture conditions and screening of lacasse activities}

Lacasse production abilities of basidiomycetes isolates were tested during the growth under agitated culture conditions. After incubation at $30^{\circ} \mathrm{C}$ on PDB (Acumedia) for 4 days, obtained fungal pellets were homogenized and used as inoculum. Four $\mathrm{ml}$ of homogenate was transferred into $100 \mathrm{ml}$ liquid medium in a $250 \mathrm{ml}$ flask for agitated culture conditions $\left(150 \mathrm{rev} \mathrm{min}^{-1}\right)$. To determine the best lacasse production medium, five media were evaluated including stock basal medium (SBM) (Forney and Reddy, 1979), modified Vogel medium (MVM) (Aktas et al. 2001), potato dextrose broth (PDB), mycological liquid medium (MLM) (Paice et al. 1989) and medium proposed by Mikiashvili et al. (2006). All cultures were incubated at $30^{\circ} \mathrm{C}$ for 15 days and lacasse activities were measured on 5,10 , and 15 days of incubation period.

To determine the lacasse activities of the tested isolates, $0.1 \mathrm{ml}$ of culture supernatant was added to $4.9 \mathrm{ml}$ sodium acetate buffer $(50 \mathrm{mM}, \mathrm{pH} 4.5)$, which contains $1 \mathrm{mM}$ guaiacol as substrate and incubated at $37^{\circ} \mathrm{C}$ for $15 \mathrm{~min} .1 \mathrm{U}$ of enzyme activity was defined as the amount of enzyme that elicited an increase in $A_{465}$ of 1 absorbance unit per min. Absorbance was measured with a UV-Visible spectrophotometer (Schimadzu 2550 UV-Visible), (Ünal and Kolankaya, 2001).

\section{Addition of lacasse inducers in growth medium}

Effects of some inducers on lacasse activities of selected five isolates: L. strigosus, C. unicolor, $T$. versicolor (D22), T. versicolor ATCC (200801) and S. commune (D35) were investigated. T. versicolor ATCC (200801), known to produce lacasse (Birhanli and Yesilada, 2006) was used to enhance the activity changing of medium and adding inducers. At this stage of experiment, $S$. commune was selected as negative control. In this way, $S$. commune normally not a lacasse producer, was investigated to determine whether it acquired the ability of lacasse production with inducers. Then, $\mathrm{CuSO}_{4}(1 \mathrm{mM})$, gallic acid $(1 \mathrm{mM})$, ammonium tartrate $(55 \mu \mathrm{M})$, malt extract $\left(5 \mathrm{~g} \mathrm{l}^{-1}\right)$, mannitol $\left(1 \mathrm{~g} \mathrm{I}^{-1}\right)$, 


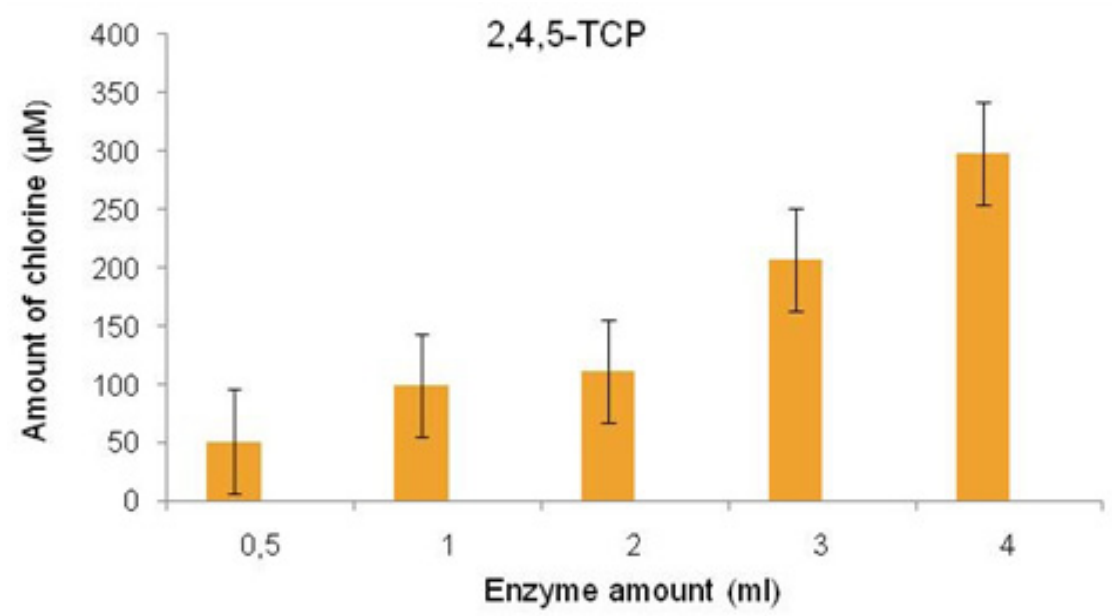

Fig. 4 Effect of enzyme amount on enzymatic dechlorination for 2,4,5-TCP (Substrate concentration: 400 $\mu \mathrm{M}$; reaction time: $30 \mathrm{~min}$; temperature: $30^{\circ} \mathrm{C} ; \mathrm{pH}: 5$ ).

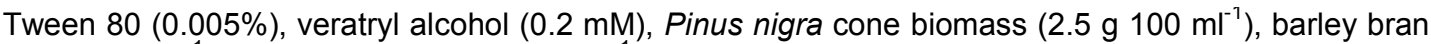

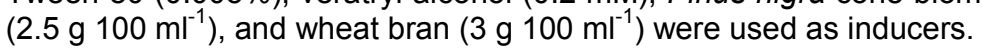

$\mathrm{CuSO}_{4}$, gallic acid, ammonium tartrate, malt extract, mannitol, Tween 80, veratryl alcohol as lacasse inducers, also 2,4,5-TCP were purchased from Merck and barley bran, wheat bran were supplied from local market.

Conditions of experiments were stable at $30^{\circ} \mathrm{C}, 150 \mathrm{rev} \mathrm{min}^{-1}$ and lacasse activities were measured at $5,8,12$ and 15 days of incubation period. To understand the effects of inducers, control cultures without inducers were run under similar conditions. Three parallel experimental media were prepared for each experiment.

\section{Optimization of studies of dechlorination}

The bioreactor used for enzymatic dechlorination studies, consisted of reactor vessel, stirred-heating system and waterbath with temperature control. On this study, the bioreactor designed by Ünal and Kolankaya (2004) was used.

Incubation time (1-120 min), $\mathrm{pH}$ (3-9), initial substrate concentration (50-500 $\mu \mathrm{M})$, temperature (10$50^{\circ} \mathrm{C}$ ) enzyme amount $(0.5-4 \mathrm{ml})$ were the parameters tested for this purpose in the bioreactor with constant working volume at $100 \mathrm{ml}$.

At $\mathrm{pH}$ optimization, for $\mathrm{pH} 3-5$, sodium acetate-acetic acid buffer; for $\mathrm{pH}$ 6-8, $\mathrm{Na}_{2} \mathrm{HPO}_{4}-\mathrm{NaH}_{2} \mathrm{PO}_{4}$ buffer; for $\mathrm{pH}$ 9-10, Tris- $\mathrm{HCl}$ buffer were used.

Reaction volume, amount of chlorophenolic compound, medium temperature were kept constant as $100 \mathrm{ml}, 1 \mathrm{ml}$ and $30 \pm 1^{\circ} \mathrm{C}$, respectively. While enzyme activity was $29.08 \mathrm{U} \mathrm{ml}^{-1}$ for dechlorination, $1 \%$ ethanol was added to the bioreactor medium for dissolving 2,4,5-TCP. Control experiments were also performed containing all reactants but no active enzyme. All the experiments were carried out in triplicate.

\section{Measurement of free chlorine and dissolved oxygen}

The variations in the amount of dissolved oxygen were detected by oxygen electrode (WTW). Free chloride ions produced upon oxidation of the chlorinated substrates were analyzed spectrophotometrically by the mercury thiocyanate method (Greenberg et al. 1992). 
Table 1. Effects of different inducers on lacasse activity in liquid cultures and PDB medium at shaking conditions.

\begin{tabular}{|c|c|c|c|c|c|c|c|c|c|c|c|c|c|c|c|c|c|c|c|c|}
\hline \multirow[b]{2}{*}{ Days inducers } & \multicolumn{4}{|c|}{$\begin{array}{l}\text { Schizophyllum } \\
\text { commune } \\
\text { D35 }\end{array}$} & \multicolumn{4}{|c|}{$\begin{array}{c}\text { Trametes } \\
\text { versicolor } \\
\text { ATCC200801 }\end{array}$} & \multicolumn{4}{|c|}{$\begin{array}{l}\text { Trametes } \\
\text { versicolor } \\
\text { D22 }\end{array}$} & \multicolumn{4}{|c|}{$\begin{array}{c}\text { Cerrena } \\
\text { unicolor } \\
\text { D30 }\end{array}$} & \multicolumn{4}{|c|}{$\begin{array}{l}\text { Lentinus } \\
\text { strigosus } \\
\text { D26 }\end{array}$} \\
\hline & 5 & 8 & 12 & 15 & 5 & 8 & 12 & 15 & 5 & 8 & 12 & 15 & 5 & 8 & 12 & 15 & 5 & 8 & 12 & 15 \\
\hline Control $\left(\mathrm{U} \mathrm{ml}^{-1}\right)$ & 0 & 0 & 0.05 & 0.08 & 2.87 & 4.27 & 4.32 & 5.67 & 0 & 0.01 & 0.02 & 0.03 & 0 & 0 & 0.35 & 0.08 & 0 & 0 & 0 & 0 \\
\hline $\mathrm{CuSO}_{4}\left(\mathrm{U} \mathrm{ml}^{-1}\right)$ & 0 & 0.08 & 0.05 & 0.08 & 17.79 & 23.68 & 16.4 & 13.76 & 6.08 & 22.06 & 18.03 & 20.06 & 4.71 & 12.93 & 24.06 & 16.1 & 0 & 0 & 0 & 0 \\
\hline Gallic acid $\left(\mathrm{U} \mathrm{ml}^{-1}\right)$ & 0 & 0 & 0 & 0 & 2.85 & 3.77 & 3.97 & 5.53 & 0 & 0 & 0 & 0.16 & 0 & 0 & 0 & 0 & 0 & 0 & 0 & 0.16 \\
\hline Ammonium Tartrate $\left(\mathrm{U} \mathrm{ml}^{-1}\right)$ & 0 & 0 & 0 & 0 & 2.86 & 3.99 & 5.35 & 7.3 & 0 & 0 & 0 & 0.24 & 0 & 0 & 0 & 0 & 0 & 0 & 0 & 0 \\
\hline Malt extract $\left(\mathrm{U} \mathrm{ml}^{-1}\right)$ & 0 & 0 & 0 & 0 & 3.06 & 3.76 & 4.91 & 4.50 & 0.02 & 0 & 0 & 0.17 & 0 & 0 & 0 & 0 & 0 & 0 & 0 & 0 \\
\hline Barley bran $\left(\mathrm{U} \mathrm{ml}^{-1}\right)$ & 0 & 0.03 & 0 & 0 & 17.93 & 18.15 & 15.54 & 8.44 & 15.06 & 12.8 & 20.33 & 7.86 & 4.05 & 3.9 & 1.76 & 0.69 & 0 & 0 & 2.19 & 0.69 \\
\hline Wheat bran $\left(\mathrm{U} \mathrm{ml}^{-1}\right)$ & 0 & 0.10 & 0 & 0 & 12.83 & 25.78 & 29.0 & 22.00 & 18.76 & 17.46 & 18 & 10.24 & 17.2 & 19.28 & 16.22 & 6.44 & 0 & 2.3 & 7.84 & 4.66 \\
\hline Tween $80\left(\mathrm{U} \mathrm{ml}^{-1}\right)$ & 0 & 0 & 0 & 0 & 2.99 & 3.73 & 2.5 & 4.10 & 0.04 & 0.03 & 1.82 & 0.14 & 0 & 0 & 0 & 0 & 0 & 0 & 0 & 0 \\
\hline Veratryl alcohol $\left(\mathrm{U} \mathrm{ml}^{-1}\right)$ & 0 & 0 & 0 & 0 & 14.17 & 21.35 & 13.65 & 10.49 & 5.90 & 4.27 & 2.42 & 11.48 & 2.8 & 4.49 & 2.62 & 1.23 & 0 & 0 & 0 & 0 \\
\hline Mannitol $\left(\mathrm{U} \mathrm{ml}^{-1}\right)$ & 0 & 0 & 0 & 0 & 2.90 & 3.67 & 4.87 & 4.95 & 0 & 0 & 0 & 0.08 & 0 & 0 & 0 & 0 & 0 & 0 & 0 & 0 \\
\hline $\begin{array}{l}\text { Cone biomass of } \\
\text { Pinus nigra }\left(\mathrm{U} \mathrm{ml}{ }^{-1}\right)\end{array}$ & 0 & 0 & 0 & 17.5 & 3.19 & 5.41 & 8.91 & 18.59 & 9.42 & 7.56 & 6.04 & 15.7 & 0 & 0 & 0 & 17.5 & 0 & 0 & 0.05 & 0 \\
\hline
\end{tabular}




\section{Toxicity measurements}

Acute toxicity was investigated by determining the luminescence inhibition of the Vibrio fischeri NRRL number B-11177, formerly known as Photobacterium phosphoreum. Sodium thiosulphate (1\%) was used to retain chlorine. A vial of commercial toxicity testing bacterium was purchased in freeze-dried form from Strategic Diagnostics Inc. (SDI, Newark, DE, USA) and activated by reconstitution solution (Azur). The light emission of this bacterium in contact with different samples such as the chlorinated solution including denatured enzyme as the control group and the dechlorinated solution including active enzyme as the experiment group and 5, and $15 \mathrm{~min}$ of exposure times was measured using the Microtox® 500 analyzer according to Basic Test Protocol. The luminescence was recorded at $490 \mathrm{~nm}$. The data were processed using the Microtox Omni Software. The concentration of the sample producing $50 \%$ decrease in light after exposure for $15 \mathrm{~min}$ was defined as the effective concentration $\left(\mathrm{EC}_{50}\right)$.

\section{RESULTS AND DISCUSSION}

\section{Selection of potent lacasse producer}

Twenty isolates and T. versicolor ATCC (200801) were investigated in the five different media in respect of abilities of lacasse production. The most effective microorganisms and media were selected at screening stage. In the result of screening study, isolates of S. commune (D35) as negative control, C. unicolor (D30), T. versicolor (D22) and L. strigosus (D26) and T. versicolor ATCC (200801) and medium of PDB were chosen for determining effects of inducers on activity. The values of enzyme activities were shown in Figure 1.

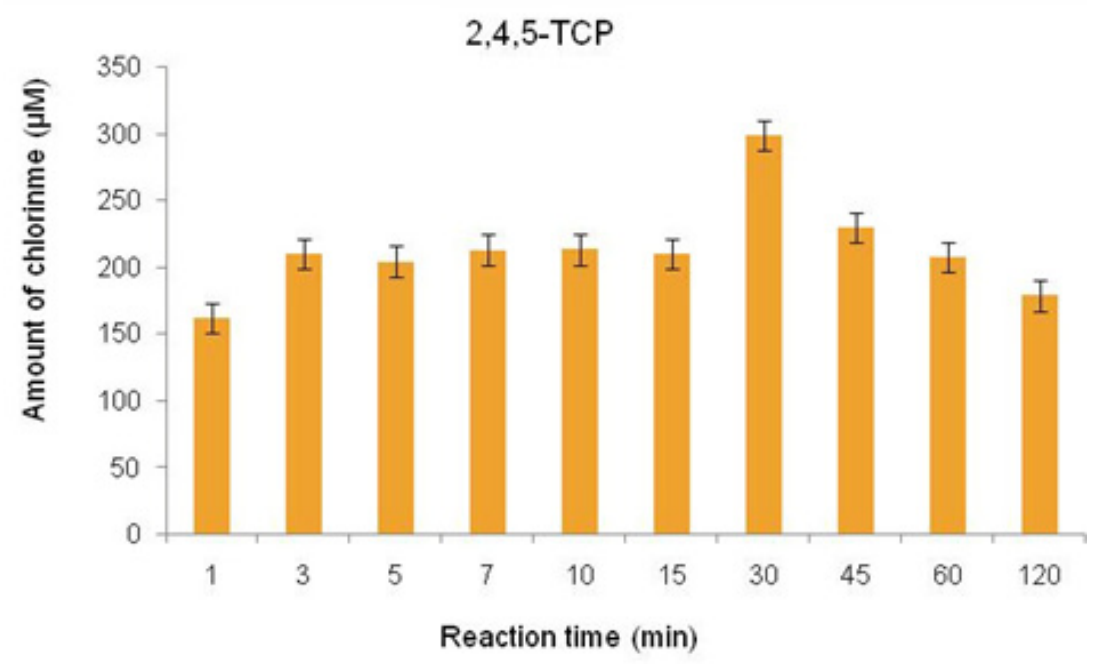

Fig. 5 Effect of reaction time on enzymatic dechlorination for 2,4,5-TCP (Substrate concentration: $400 \mu \mathrm{M}$; enzyme amount: $4 \mathrm{ml}$; temperature: $30^{\circ} \mathrm{C}$; $\mathrm{pH}$ : 5 ).

\section{Effects of lacasse inducers}

Various inducers were tested to increase activities by lacasse of S. commune (D35), C. unicolor (D30), T. versicolor (D22), L. strigosus (D26) and T. versicolor ATCC (200801). As it can be deduced from Table 1, the best results were observed in T. versicolor (D22) grown on medium with $\mathrm{CuSO}_{4}(22.06 \mathrm{U}$ $\mathrm{ml}^{-1}$ ), barley bran $\left(20.33 \mathrm{U} \mathrm{ml}^{-1}\right.$ ) and wheat bran (18.76 $\left.\mathrm{U} \mathrm{ml}^{-1}\right)$, in C. unicolor (D30) grown on medium with $\mathrm{CuSO}_{4}\left(24.06 \mathrm{U} \mathrm{ml}^{-1}\right)$, wheat bran $\left(19.28 \mathrm{U} \mathrm{ml}^{-1}\right)$ and $P$. nigra cone biomass $\left(17.50 \mathrm{U} \mathrm{ml} l^{-1}\right)$ in $T$. versicolor ATCC (200801) was grown on $\mathrm{CuSO}_{4}\left(23.68 \mathrm{U} \mathrm{ml}^{-1}\right)$, barley bran $\left(18.15 \mathrm{U} \mathrm{ml}^{-1}\right)$, wheat bran 
(25.78 $\left.\mathrm{U} \mathrm{ml}^{-1}\right)$, veratryl alcohol $\left(21.35 \mathrm{U} \mathrm{ml}^{-1}\right), P$. nigra cone biomass $\left(18.59 \mathrm{U} \mathrm{ml}^{-1}\right)$ according to Table 1.

\section{Dechlorination of 2,4,5-TCP}

During the experiments related to dechlorination, $\mathrm{pH}$, initial substrate concentration, enzyme amount, reaction time, and temperature were selected as $5,400 \mu \mathrm{M}, 4 \mathrm{ml}, 30 \mathrm{~min}, 50^{\circ} \mathrm{C}$, respectively (Figure 2, Figure 3, Figure 4, Figure 5 and Figure 6). Furthermore dissolved oxygen reduced from $3.57 \mathrm{mg} \mathrm{I}^{-1}$ to $3.21 \mathrm{mg} \mathrm{I}^{-1}$ under the determined optimization conditions.

\section{Evaluation of toxicity values}

Bioassays for acute toxicity to $V$. fischeri showed that the bacterial $\mathrm{EC}_{50}$ for the 2,4,5-TCP was not significantly changed. While $\mathrm{EC}_{50}$ concentrations for $15 \mathrm{~min}$ before and after enzymatic treatment were $61.0 \%$ and $62.0 \%$ respectively. Toxicity values of 2,4,5-TCP for 5 and 15 min before and after enzymatic treatment, was given as \% effect, as shown in Figure 7 and Figure 8.

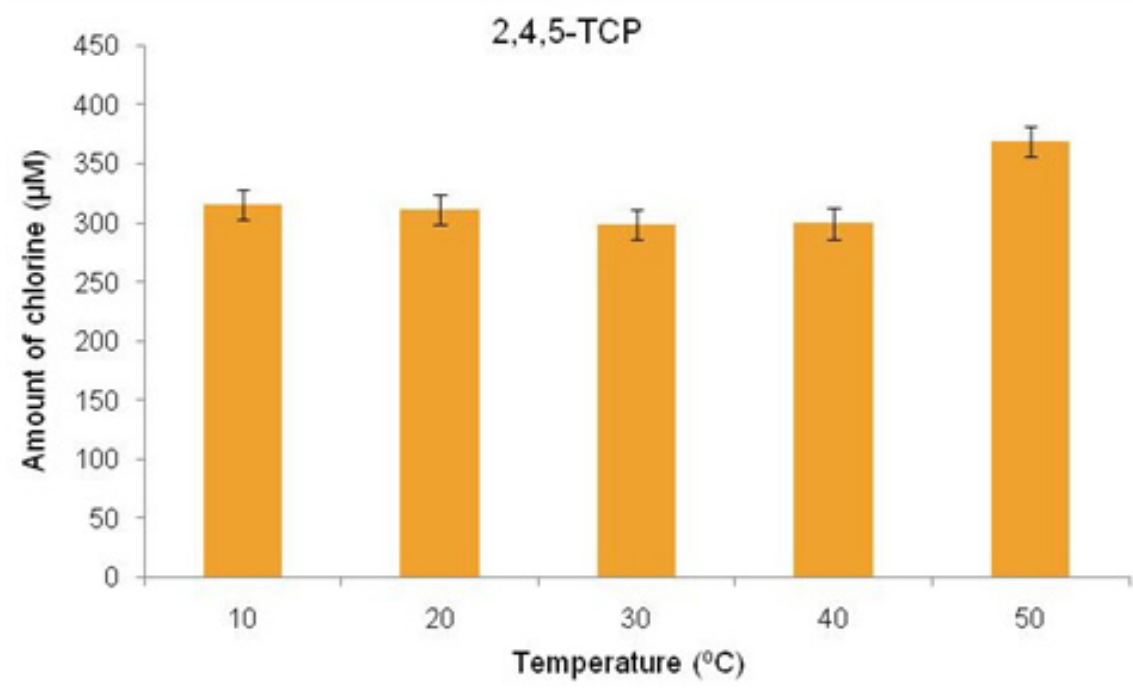

Fig. 6 Effect of temperature on enzymatic dechlorination for 2,4,5-TCP (Substrate concentration: $400 \mu \mathrm{M}$; enzyme amount: $4 \mathrm{ml}$; reaction time: $30 \mathrm{~min}$; $\mathrm{pH}$ : 5).

\section{DISCUSSION}

Lacasse, one of the enzymes of phenol oxidase group, has high potential for industrial biotechnology. Many studies have been devoted to identify the most efficient lacasse-producing source; to select the most suitable culture medium; to developing appropriate, reproducible, and inexpensive isolation procedures; and mainly to optimize the enzyme production (Gianfreda et al. 1999; Arora and Gill, 2001; Mikiashvili et al. 2006). Also, there are many studies engaged with the type, the time of addition inducers and the concentration of the inducers to enhance the lacasse production. Most of the used inducers are phenolic or aromatic compounds related to lignin or lignin derivates (Klonowska et al. 2001; Myasoedova et al. 2008).

In this study, 20 basidiomycetes isolates such as $P$. arcularius (T438), S. commune (T701), C. truncatus (T192), P. eryngii (M102), G. applanatum (M105), T. versicolor (D22), C. unicolor (D30), S. commune (D35), G. lucidum (D33), P. ostreatus (M119), T. hirsuta (T587), P. arcularius (T761), $T$. versicolor (M96), F. fomentarius (M100), A. serialis (M101), I. hispidus (M106), L. betulina (S2), S. hirsutum (B3), T. panuoides (SV2), L. strigosus (D26) and T. versicolor ATCC (200801) were examined to investigate their effects on the lacasse production under a variety of culture conditions. Types and 
amounts of carbon and nitrogen content are fundamental to lacasse formation. Among of the five media, PDB and MVM showed maximum lacasse activity (Figure 1). MVM composed of many components and it was a costly medium. That is why further experiments were continued to use PDB though MVM was an effective medium. Besides, in comparison to MVM, PDB is a basic medium; thereby, investigating effects of inducers would be easier.

After screening the study of media and isolates, different inducers were added to PDB for understanding the effects of lacasse production of the five examined fungi (Table 1). Gallic acid, malt extract and mannitol were shown that they did not affect lacasse activity positively compared to control groups for all isolates studied.

The experimental results from the screening studies show that limited production of lacasse enzyme from S. commune (D35). In relevant literatures, it is possible to show the studies to production of lacasse by using S. commune without any inducer (Leonard and Phillips, 1973). However, in this study, lacasse was efficiently produced by $S$. commune (D35) once, in the presence of pinus cone biomass increasing lacasse production in batch cultivation. On the other hand, we can not find any study in literature concerned with $P$. nigra cone biomass as lacasse inducer. According to Micales et al. (1994), the chemical composition of pinus cone was investigated and composed of lignin derivatives. Nevertheless, detailed research relevant to this matter needs to be carried out and components of cone biomass to induce activity are required for determination.

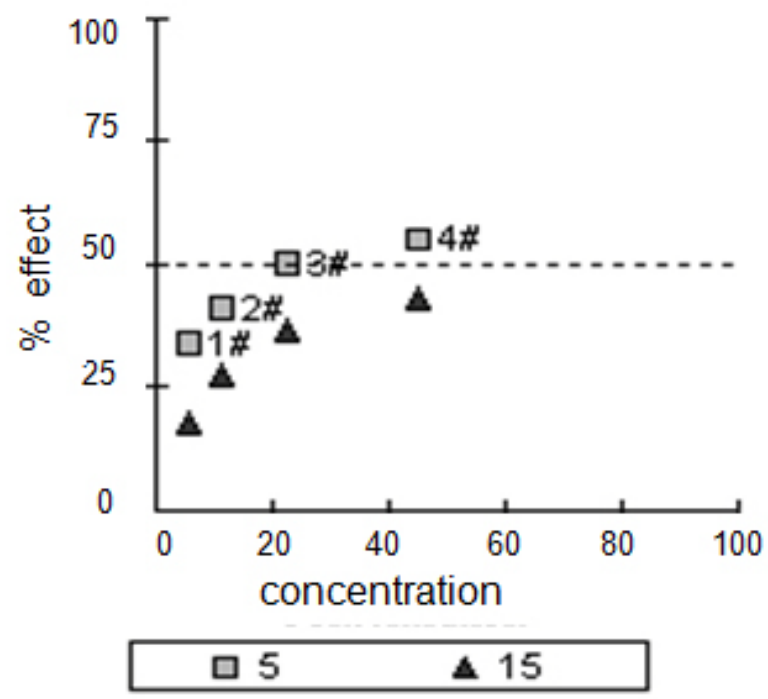

Fig. 7 Toxicity values of 2,4,5-TCP before enzymatic treatment.

It is well documented that both the type and concentration of nitrogen in culture media for growing white rot fungi are essential to lacasse production (Galhaup et al. 2002). Our study demonstrated that ammonium tartrate as inducer affected only T. versicolor ATCC (200801) lacasse positively, from 5.67 $\mathrm{U} \mathrm{ml} l^{-1}$ to $7.30 \mathrm{U} \mathrm{ml}^{-1}$ after 15 days. Other isolates tested were not induced with ammonium tartrate. It was reported that Lentinula edodes cultures with ammonium tartrate exhibited lacasse activity higher than control cultures, reaching $251 \mathrm{U} \mathrm{ml}^{-1}$ of extract after 30 days by Cavallazi et al. (2005).

A nonionic surfactant, Tween 80 only showed an effect on $T$. versicolor (D22) lacasse and while control group had $0.02 \mathrm{U} \mathrm{ml}^{-1}$ of enzyme activity, broth with Tween 80 reached to $1.82 \mathrm{U} \mathrm{ml}^{-1}$ on 12 days of incubation period.

Veratryl alcohol is oxidized by lacasse and it is thought to be involved in lignin degradation. Thereby, an affirmative effect shows at enzyme production of many fungi. The inductive effect of veratryl alcohol on lacasse production by Polyporus sanguineus, Daedalea flavida, Phlebia brevispora, and Phlebia 
radiata has been reported in the earlier studies (Arora and Gill, 2001). In our experiments, lacasse activities reached at $4.49 \mathrm{U} \mathrm{ml}^{-1}, 11.48 \mathrm{U} \mathrm{ml}^{-1}$ and $21.35 \mathrm{U} \mathrm{ml}^{-1}$ in the presence of veratryl alcohol for $C$. unicolor (D30), T. versicolor (D22) and T. versicolor ATCC (200801), respectively.

A waste biomass of agriculture, barley bran containing lignin, was evaluated in respect of induction. We observed that activities of enzyme increased except for lacasse synthesized from S. commune (D35). In the presence this inducer, 4-fold increase was performed for $C$. unicolor (D30) after five days while $T$. versicolor (D22) lacasse activity increased 20-fold after 12 days of incubation period. Activity of lacasse produced from T. versicolor ATCC (200801) enhanced 6-fold thanks to barley bran after 5 days of the incubation period. Rosales et al. (2002) studied lacasse production of Trametes hirsuta with barley bran in solid conditions and enzyme production of this culture began on the day $4\left(230 \mathrm{U} \mathrm{I}^{-1}\right)$. Then, it peaked on the day $8\left(2247 \mathrm{U} \mathrm{I}^{-1}\right)$ and hereafter it decreased. According to reports of Moldes et al. (2004) barley bran cultures gave the highest lacasse activities, showing values of 2500-3200 U I-1 from the day 20 to the day 35, that of barley straw cultures exhibited values of about 300-500 $\mathrm{U} \mathrm{I}^{-1}$ at the same days. Schlosser et al. (1997) proposed the mechanism for these materials to induce the lacasse production is the presence of little quantities of phenolic soluble compounds. Similarly, in a previous work (Lorenzo et al. 2002), the production of lacasse by $T$. versicolor in submerged cultures was optimized by addition of different lignocellulosic residues. Of those, barley bran gave the highest activities (639 $\mathrm{U} \mathrm{I}^{-1}, 12$-fold to control culture).

Wheat bran was also used as lacasse inducer. Isolates used apart from S. commune (D35) had high lacasse activity when wheat bran was added into culture broth. Findings showed that lacasse activities of $T$. versicolor ATCC (200801), T. versicolor (D22), C. unicolor (D30) and L. strigosus (D26) reached up to $29.08,18.76,19.28$ and $7.84 \mathrm{U} \mathrm{ml}^{-1}$, respectively. Literature screening indicated that wheat bran was frequently used as one of the inducers (Arora and Gill, 2001; Lechner and Papinutti, 2006; Murugesan et al. 2007). Wheat bran as well as barley bran has more advantage than chemical inducers due to the fact that it is natural biomass. Nyanhongo et al. (2002) studied the effects of the carbon and nitrogen sources, initial $\mathrm{pH}$ and incubation temperature on lacasse production by Trametes modesta. They evaluated using the one-factor-at-a-time method. Response-surface analysis showed that $7.34 \mathrm{~g} \mathrm{l}^{-1}$ wheat bran, $0.87 \mathrm{~g} \mathrm{I}^{-1}$ glucose, $2.9 \mathrm{~g} \mathrm{l}^{-1}$ yeast extract, $0.25 \mathrm{~g} \mathrm{l}^{-1}$ ammonium chloride were the optimal amounts for lacasse production.

Copper was used as stimulating agent for the production of lacasse. Our study demonstrated $\mathrm{CuSO}_{4}(1$ $\mathrm{mM}$ ) as inducer affected all isolates studied apart from $L$. strigosus (D26) and S. commune. The activity of lacasse produced from C. unicolor (D30) reached $24.06 \mathrm{U} \mathrm{ml}^{-1}$ within 12 days that of $T$. versicolor (D22) reached $22.06 \mathrm{U} \mathrm{ml}^{-1}$ after 8 days and that of $T$. versicolor ATCC (200801) increased up to 23.68 $\mathrm{U} \mathrm{ml}^{-1}$ in a batch cultures. A previous report showed the effect of copper on lacasse activity (Birhanli and Yesilada, 2006). They observed that lacasse activities of growing cells of Funalia trogii and $T$. versicolor in copper-supplemented in repeated-batch cultures were increased to 40.29 and $12.09 \mathrm{U} \mathrm{ml}^{-}$ 1 , respectively while in the Cu-free repeated-batch cultures of $F$. trogii and $T$. versicolor pellets, maximum lacasse activities were found 0.83 and $0.61 \mathrm{U} \mathrm{ml}^{-1}$, respectively. Also, the induction of lacasse by copper has already been documented in P. ostreatus. Baldrian and Gabriel (2002) indicated that the addition of copper $(0.5-5 \mathrm{mM})$ to the white rot fungus $P$. ostreatus cultivated in liquid nitrogenlimited medium for 12 days increased the activity of lacasse and the addition of $1 \mathrm{mM}$ copper led to eight fold increase of activity. The results show that the presence of copper as a metal activator plays a key role in the regulation of extracellular enzyme activities, especially in oxidase and superoxidase group enzyme activities. Because copper is a component which is in the lacasse prostetic group presenting four cupric ions each associated with one single polypeptide chain, it is therefore an important component of active lacasse structure (Thurston, 1994). Besides, it has been proved that this ion may play an important role in lacasse genes regulation at transcription level as showed in $T$. versicolor (Collins and Dobson, 1997), Pleurotus sajor-caju (Soden and Dobson, 2001), P. ostreatus (Palmieri et al. 2000).

According to results of this study, different lacasse activity was obtained for both $T$. versicolor. Difference of lacasse activities between T. versicolor ATCC (200801) and T. versicolor (D22) may depend on the type and localization of fungal strain used.

Potentials of lacasse production of $S$. commune and $C$. unicolor without adding an inducer were reported in previous studies (De Vries et al. 1986; Kim et al. 2002; Stepanova et al. 2003). Myasoedova et al. (2008) studied with L. strigosus by inserting inducer such as $\mathrm{CuSO}_{4}$ and 2,6dimethylphenol and found $186.5 \mathrm{U} \mathrm{ml}^{-1}$. This high lacasse activity may result from localization of 
isolation and type of inducers used. The effect of inducers on the lacasse production of these fungal biomasses were investigated under identical conditions. As can be seen in Table 1, lacasse activity reached to $24.06 \mathrm{U} \mathrm{ml}^{-1}$ for $C$. unicolor with using $\mathrm{CuSO}_{4}$ as an inducer in $\mathrm{PDB}$ medium. Also, lacasse activity was obtained at $17.50 \mathrm{U} \mathrm{ml}^{-1}$ for both $S$. commune and $C$. unicolor with $P$. nigra cone biomass in the PDB medium. Besides, lacasse activity was induced up to $7.84 \mathrm{U} \mathrm{ml}^{-1}$ with wheat bran for $L$. strigosus. These results indicated that $S$. commune and $C$. unicolor cells may be used as an inexpensive, effective and easily induced alternative lacasse producer.

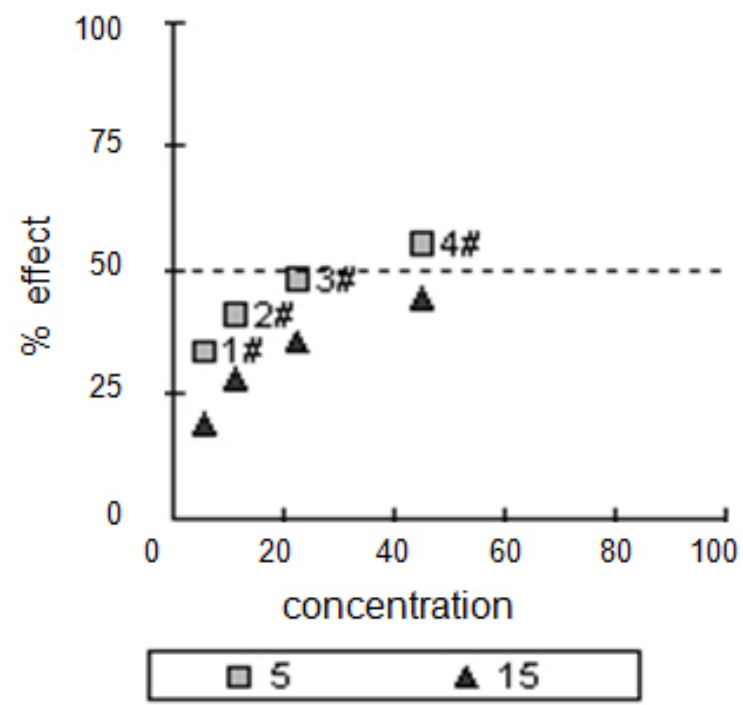

Fig. 8 Toxicity values of 2,4,5-TCP after enzymatic treatment.

In our study, chlorine removal from 2,4,5-TCP was examined as a environmental application. This application was performed with the highest activity of lacasse using wheat bran as an inducer. According to these results, $79.74 \%$ of dechlorination of 2,4,5-TCP was obtained on optimum conditions which were $\mathrm{pH} 5,400 \mu \mathrm{M}$ of initial substrate concentration, $30 \mathrm{~min}$ of reaction period, $4 \mathrm{ml}$ of enzyme amount, and $50^{\circ} \mathrm{C}$ of temperature (Figure 2, Figure 3, Figure 4, Figure 5 and Figure 6). Madsen and Aamand (1992) studied transformation of TCPs and they rapidly resumed after heating of the culture at $80^{\circ} \mathrm{C}$ for $1 \mathrm{hr}$, suggesting that the dechlorinating bacteria are spore-forming anaerobes. 2,4,5-TCP was dechlorinated to 3,4-dichlorophenol at initial concentrations of $\leq 40 \mu \mathrm{M}$. Stazi et al. (2001) dechlorinated 2,4,6-TCP, a trichlorophenol compound, by mixture of peroxidase isozymes from Vaccinium myrtillus and investigated the effect of $\mathrm{pH}$, temperature, reaction time, enzyme amount and initial pollutant concentration on the treatment efficiency in order to optimize the reaction conditions for TCP removal. According these results, at the extreme values of the range considered, at 0,1 and $20 \mu \mathrm{mol} \mathrm{\textrm {dm } ^ { - 3 }}$ of TCP, the removal efficiency of 2,4,6-TCP was about 96 and $50 \%$. Besides, in the pH range $3.0 \pm 9.0$, the optimal value was found to be 5.0. The effect of temperature on the extent of TCP transformation was also studied between 20 and $60^{\circ} \mathrm{C}$. At earlier incubation periods, peroxidase was most active at $30^{\circ} \mathrm{C}$ but the relative differences observed between the various temperatures were less prominent when evaluating longer reaction times. Furthermore, the amount of substrate removal was increased with increasing amounts of peroxidase.

The dechlorination of 2,4-dichloro, 2,4,5-trichloro, 2,4,6-trichloro and pentachlorophenol by the lignin peroxidase of Phanerochaete chrysosporium has been reported (Hammel and Tardone, 1988). In this process, the release of chloride ions from single polychlorophenols was accompanied by both oxygen consumption and substrate disappearance. In addition to the fact that the chlorine removal from chlorophenols depended on the chemical structure and concentration of the substrate, $\mathrm{pH}$ of the reaction mixture, activity of the enzyme, length of incubation, and temperature (Stazi et al. 2001).

Bollag et al. (1988) studied lacasse of the fungus Rhizoctonia praticola, to detoxify phenolic pollutants such as o-chlorophenol, p-chlorophenol, 2,4-dichlorophenol, 2,4,5-TCP, 4-chloro-2-methylphenol. 
However, toxicity of $p$-chlorophenol and 2,4,5-TCP could not be overcome by a lacasse mediated system.

According to the experiments of Joshi and Gold (1993) P. chrysosporium mineralized 2,4,5-TCP through its enzymes of LiP and MnP. The multistep pathway involves cycles of peroxidase-catalyzed oxidative dechlorination reactions followed by quinone reduction reactions to yield of the key intermediate 1,2,4,5-tetrahydroxybenzene, which is presumably ring cleaved with subsequent degradation to $\mathrm{CO}_{2}$. In this pathway, the substrate is oxidatively dechlorinated by LiP or MnP in a reaction which produces a quinone. The quinone intermediate is recycled by a reduction reaction to regenerate an intermediate which is again a substrate for peroxidase-catalyzed oxidative dechlorination. This pathway apparently results in the removal of all three chlorine atoms before ring cleavage occurs.

Itoh et al. (2000) reported phenolic acids affect transformations of chlorophenols by a $T$. versicolor lacasse (IFO 30340). 3- and 4-chlorophenols, 2,5-, 3,4- and 3,5-dichlorophenols, 2,4,5-TCP and pentachlorophenol, recalcitrant compounds to the lacasse could have transformed through phenolic acids such as sinapinic acid, ferulic and p-cumaric acid.

According to the study of Roper et al. (1995), addition of $50 \mathrm{mM}$ guaiacol as a reactive cosubstrate enhanced the dechlorination of 4-chlorophenol, 2,4-dichlorophenol, and 2,4,5-TCP with peroxidase by 12,32 and $65 \%$, respectively, and with lacasse by 20,32 and $80 \%$, respectively.

Similar toxicity values were observed in our study after dechlorination experiments compared to the parent compound. Our results showed that only the denatured control containing 2,4,5-TCP, was sufficiently toxic to the bacterium $\mathrm{V}$. fischeri, resulting in a 15 min $\mathrm{EC}_{50}$ of $61.00 \%$. The dechlorination samples were serially diluted before being tested with the bioluminescent bacterium because the bacterium only shows a response to toxic compounds when these compounds are present by a concentration below the sub-lethal concentration ( $\mathrm{Gu}$ and Choi, 2001). As expressed in Figure 7 and Figure 8 , the given \% effects demonstrated that the toxicities of the parent compound and the intermediates were similar. This enzymatic procedure suggested that 2,4,5-TCP dechlorination metabolites by $T$. versicolor lacasse was an environmental friendly strategy, there was no contribution to total toxicity. Evgenidou et al. (2005a) and Evgenidou et al. (2005b) investigated the removal of dichlorvos and dimethoate mediated photocatalytic process. They proved that photocatalytic treatment was not always capable of reducing the toxicity of dimethoate or dichlorvos solutions. Moreover, a slight increase could sometimes be observed. Marco-Urrea et al. (2010) studied degradation of the drug sodium diclofenac by $T$. versicolor pellets and evaluated toxicity by the Microtox bioassay. They found that uninoculated control including at $10 \mathrm{mg} \mathrm{I}^{-1}$ was toxic to the luminescence bacterium, resulting in a 15 min $\mathrm{EC}_{50}$ of $34.0 \%$. Choi and Gu (2003) degraded 2,4,5-TCP by Phanerochaete chrysosporium assessed toxicity, and detected reducement of toxicity. These results compared to our results showed that degradation products of 2,4,5-TCP was lesser toxic than parent compound, while dechlorination products of 2,4,5-TCP were similar toxicity values. Gan et al. (2002) examined dechlorination of chloroacetanilide herbicides including alachlor, acetachlor, metolachlor, and propachlor by thiosulphate salts and toxicity after this process. Dissipation of $200 \mu \mathrm{M}$ of alachlor was performed in $100 \mathrm{hrs}$ through sodium thiosulphate and observed toxicological alterations, increasing $E_{50}$. However, the more recalcitrant compound, 2,4,5-TCP was dechlorinated in 30 min in our study.

In conclusion, the lacasse formation potential of the isolates studied can be enhanced several fold on supplementing the basal media with various natural or chemically synthesized materials and obtained lacasse can be utilized in several biotechnological applications. In this study, the induced lacasse obtained has shown usability at dechlorination of 2,4,5-TCP; besides, toxicity was tested. Enzymatic treatment with lacasse would not always lead to complete detoxification in a previous stage probably requiring higher quantities of biocatalyst or sequential enzymatic treatment after the dechlorination process. Further research is needed to investigate different inducers in this process and mechanisms of induction. Also, it can be determined that lacasse inducers based on lignin derivative compounds cause whether the amount of lignin change.

\section{ACKNOWLEDGMENTS}

This study is partially based on the MSc thesis of S. Gedikli, who is one of the authors. 
Financial support: Eskişehir Osmangazi University Scientific Research Project Committee, project number 200819021.

\section{REFERENCES}

AKTAŞ, N.; ÇIÇEK, H.; ÜNAL, A.T.; KIBARER, G.; KOLANKAYA, N. and TANYOLAÇ, A. (2001). Reaction kinetics for lacasse-catalyzed polymerization of 1-naphthol. Bioresource Technology, vol. 80, no. 1, p. 29-36. [CrossRef]

ARORA, D.S. and GILL, P.K. (2001). Effects of various media and supplements on lacasse production by some white rot fungi. Bioresource Technology, vol. 77, no. 1, p. 89-91. [CrossRef]

AYTAR, P.; ŞAM, M. and ÇABUK, A. (2008). Microbial desulphurization of Turkish lignites by white rot fungi. Energy \& Fuels, vol. 22, no. 2, p. 1196-1199. [CrossRef]

BABOROVÁ, P.; MÖDER, M.; BALDRIAN, P.; CAJTHAMLOVÁ, K. and CAJTHAML, T. (2006). Purification of a new manganese peroxidase of the white-rot fungus Irpex lacteus, and degradation of polycyclic aromatic hydrocarbons by the enzyme. Research in Microbiology, vol. 157, no. 3, p. 248-253. [CrossRef]

BALDRIAN, P. and GABRIEL, J. (2002). Copper and cadmium increase lacasse activity in Pleurotus ostreatus. FEMS Microbiology Letters, vol. 206, no. 1, p. 69-74. [CrossRef]

BIRHANLI, E. and YESILADA, O. (2006). Increased production of lacasse by pellets of Funalia trogii ATCC 200800 and Trametes versicolor ATCC 200801 in repeated-batch mode. Enzyme and Microbial Technology, vol. 39, no. 6, p. 1286-1293. [CrossRef]

BOLLAG, J.-M.; SHUTTLEWORTH, K. and ANDERSON, D.H. (1988). Lacasse-mediated detoxification of phenolic compounds. Applied and Environmental Microbiology, vol. 54, no. 12, p. 3086-3091.

ÇABUK, A.; ÜNAL, A.T. and KOLANKAYA, N. (2006). Biodegradation of cyanide by a white rot fungus, Trametes versicolor. Biotechnology Letters, vol. 28, no. 16, p. 1313-1317. [CrossRef]

CAMARERO, S.; IBARRA, D.; MARTINEZ, M.J. and MARTINEZ, A.T. (2005). Lignin-derived compounds as efficient lacasse mediators for decolorization of different types of recalcitrant dyes. Applied and Environmental Microbiology, vol. 71, no. 4, p. 1775-1784. [CrossRef]

CAMERON, M.D.; TIMOFEEVSKI, S. and AUST, S.D. (2000). Enzymology of Phanerochaete chrysosporium with respect to the degradation of recalcitrant compounds and xenobiotics. Applied Microbiology and Biotechnology, vol. 54, no. 6, p. 751-758. [CrossRef]

CAVALLAZZI, J.R.P.; KASUYA, C.M. and SOARES, M.A. (2005). Screening of inducers for lacasse production by Lentinula edodes in liquid medium. Brazilian Journal of Microbiology, vol. 36, no. 4, p. 383-387. [CrossRef]

CHOI, S.H. and GU, M.B. (2003). Toxicity biomonitoring of degradation byproducts using freeze-dried recombinant bioluminescent bacteria. Analytica Chimica Acta, vol. 481, no. 2, p. 229-238. [CrossRef]

COLLINS, P.J. and DOBSON, A.D.W. (1997). Regulation of lacasse gene transcription in Trametes versicolor. Applied and Environmental Microbiology, vol. 63, no. 9, p. 3444-3450.

D'ACUNZO, F.; GALLI, C.; GENTILI, P. and SERGI, F. (2006). Mechanistic and steric issues in the oxidation of phenolic and non-phenolic compounds by lacasse or lacasse-mediator systems: The case of bifunctional substrates. New Journal of Chemistry, vol. 30, no. 4, p. 583-591. [CrossRef]

DE VRIES, O.M.H.; KOOISTRA, W.H.C.F. and WESSELS, J.G.H. (1986). Formation of an extracellular lacasse by a Schizophyllum commune dikaryon. Journal of General Microbiology, vol. 132, no. 10, p. 2817-2826. [CrossRef]

DERCOVA, K.; KYSELOVA, Z.; BARANCIKOVA, G.; SEJAKOVA, Z. and MALOVA, A. (2003). Biodegradation and bioremediation of pentachlorophenol (PCP). Chemické Listy, vol. 97, p. 991-1002.

EVGENIDOU, E.; FYTIANOS, K. and POULIOS, I. (2005a). Photocatalytic oxidation of dimethoate in aqueous solutions. Journal of Photochemistry and Photobiology A: Chemistry, vol. 175, no. 1, p. 29-38. [CrossRef]

EVGENIDOU, E.; FYTIANOS, K. and POULIOS, I. (2005b). Semiconductor-sensitized photodegradation of dichlorvos in water using $\mathrm{TiO}_{2}$ and $\mathrm{ZnO}$ as catalysts. Applied Catalysis B: Environmental, vol. 59, no. 1-2, p. 81-89. [CrossRef]

FLORES, C.; CASASANERO, R.; TREJO-HERNÁNDEZ, M.R.; GALINDO, E. and SERRANO-CARREÓN, L. (2010). Production of lacasses by Pleurotus ostreatus in submerged fermentation in co-culture with Trichoderma viride. Journal of Applied Microbiology, vol. 108, no. 3, p. 810-817. [CrossRef]

FORNEY, L.J. and REDDY, C.A. (1979). Bacterial degradation of kraft lignin. Developments in Industrial Microbiology, vol. 20, p. 163-175.

FURUKAWA, K. (2003). 'Super bugs' for bioremediation. Trends in Biotechnology, vol. 21, no. 5, p. 187-190. [CrossRef]

GALHAUP, C.; WAGNER, H.; HINTERSTOISSER, B. and HALTRICH, D. (2002). Increased production of lacasse by the wood-degrading basidiomycete Trametes pubescens. Enzyme and Microbial Technology, vol. 30, no. 4, p. 529-536. [CrossRef]

GAN, J.; WANG, Q.; YATES, S.R.; KOSKINEN, W.C. and JURY, W.A. (2002). Dechlorination of chloroacetanilide herbicides by thiosulphate salts. Proceedings of the National Academy of Sciences of the United States of America, vol. 99, no. 8, p. 5189-5194. [CrossRef]

GIANFREDA, L.; XU, F. and BOLLAG, J.-M. (1999). Lacasses: A useful group of oxidoreductive enzymes. Bioremediation Journal, vol. 3, no. 1, p. 1-26. [CrossRef]

GREENBERG, A.E.; CLESCERI, L.S. and EATON, A.D. eds. (1992). Standard methods for the examination of water and wastewater. $18^{\text {th }}$ ed. Washington DC, American Public Health Association, 1100 p. ISBN 0875532071. 
GU, M.B. and CHOI, S.H. (2001). Monitoring and classification of toxicity using recombinant bioluminescent bacteria. Water Science and Technology, vol. 43, no. 2, p. 147-154.

HAMMEL, K.E. and TARDONE, P.J. (1988). The oxidative 4-dechlorination of polychlorinated phenols is catalyzed by extracellular fungal lignin peroxidases. Biochemistry, vol. 27, no. 17, p. 6563-6568. [CrossRef]

INTERNATIONAL AGENCY FOR RESEARCH ON CANCER (IARC). (1986). Occupational exposure to chlorophenols. In: Monographs on the Evaluation of the Carcinogenic Risk of Chemicals to Humans, vol 41: Some halogenated hydrocarbons and pesticide exposure. [Updated 1999]. Lion, France, IARC Press. p. 319.

ITOH, K.; FUJITA, M.; KUMANO, K.; SUYAMA, K. and YAMAMOTO, H. (2000). Phenolic acids affect transformations of chlorophenols by a Coriolus versicolor lacasse. Soil Biology \& Biochemistry, vol. 32, no. 1, p. 85-91. [CrossRef]

JOHANNES, C. and MAJCHERCZYK, A. (2000). Natural mediators in the oxidation of polycyclic aromatic hydrocarbons by lacasse mediator systems. Applied and Environmental Microbiology, vol. 66, no. 2, p. 524528.

JOSHI, D.K. and GOLD, M.H. (1993). Degradation of 2,4,5-trichlorophenol by the lignin-degrading basidiomycete Phanerochaete chrysosponium. Applied and Environmental Microbiology, vol. 59, no. 6, p. 1779-1785.

KARGI, F. and EKER, S. (2004). Toxicity and batch biodegradation kinetics of 2,4-dichlorophenol by pure Pseudomonas putida culture. Enzyme and Microbial Technology, vol. 35, no. 5, p. 424-428. [CrossRef]

KIM, Y.; CHO, N.-S.; EOM, T.-J. and SHIN, W. (2002). Purification and characterization of a lacasse from Cerrena unicolor and its reactivity in lignin degradation. Bulletin of the Korean Chemical Society, vol. 23, no. 7, p. 985989.

KLONOWSKA, A.; LE PETIT, J. and TRON, T. (2001). Enhancement of minor lacasses production in the basidiomycete Marasmius quercophilus C30. FEMS Microbiology Letters, vol. 200, no. 1, p. 25-30. [CrossRef]

KO, E.-M.; LEE, Y.-E. and CHOI, H. (2001). Purification and characterization of lacasse isoenzymes from the white rot basidiomycete Ganoderma lucidum. Applied Microbiology and Biotechnology, vol. 57, no. 1-2, p. 98-102. [CrossRef]

KOLANKAYA, D. (2006). Organochlorine pesticide residues and their toxic effects on the environment and organisms in Turkey. International Journal of Environmental Analytical Chemistry, vol. 86, no. 1-2, p. 147160. [CrossRef]

LECHNER, B.E. and PAPINUTTI, V.L. (2006). Production of lignocellulosic enzymes during growth and fruting of the edible fungus Lentinus tigrinus on wheat straw. Process Biochemistry, vol. 41, no. 3, p. 594-598. [CrossRef]

LEONARD, T.J. and PHILLIPS, L.E. (1973). Study of phenoloxidase activity during the reproductive cycle in Schizophyllum commune. Journal of Bacteriology, vol. 114, no. 1, p. 7-10.

LORENZO, M.; MOLDES, D.; RODRÍGUEZ COUTO, S. and SANROMÁN, A. (2002). Improving lacasse production by employing different lignocellulosic wastes in submerged cultures of Trametes versicolor. Bioresource Technology, vol. 82, no. 2, p. 109-113. [CrossRef]

MADSEN, T. and AAMAND, J. (1992). Anaerobic transformation and toxicity of trichlorophenols in a stable enrichment culture. Applied and Environmental Microbiology, vol. 58, no. 2, p. 557-561.

MARCO-URREA, E.; PÉREZ-TRUJILLO, M.; CRUZ-MORATÓ, C.; CAMINAL, G. and VICENT, T. (2010). Degradation of the drug sodium diclofenac by Trametes versicolor pellets and identification of some intermediates by NMR. Journal of Hazardous Materials, vol. 176, no. 1-3, p. 836-842. [CrossRef]

MICALES, J.A.; HAN, J.S.; DAVIS, J.L. and YOUNG, R. (1994). Chemical composition and fungitoxic activities of pine cone extractives. In: LLEWELLYN, G.C.; DASHEK, W.V. and O'REAR, C.E., eds. Biodeterioration Research 4: Mycotoxins, wood decay, plant stress, biocorrosion, and general biodeterioration. New York, Plenum Press, p. 317-332.

MIKIASHVILI, N.; WASSER, S.P.; NEVO, E. and ELISASHVILI, V. (2006). Effects of carbon and nitrogen sources on Pleureotus ostreaus ligninolytic enzyme activity. World Journal of Microbiology and Biotechnology, vol. 22, no. 9, p. 999-1002. [CrossRef]

MOLDES, D.; LORENZO, M. and SANROMÁN, M.A. (2004). Different proportions of lacasse isoenzymes produced by submerged cultures of Trametes versicolor grown on lignocellulosic wastes. Biotechnology Letters, vol. 26, no. 4, p. 327-330. [CrossRef]

MURUGESAN, K.; NAM, I.-H.; KIM, Y.-M. and CHANG, Y.-S. (2007). Decolorization of reactive dyes by a thermostable lacasse produced by Ganoderma lucidium in solid state culture. Enzyme and Microbial Technology, vol. 40, no. 7, p. 1662-1672. [CrossRef]

MYASOEDOVA, N.M.; CHERNYKH, A.M.; PSURTSEVA, N.V.; BELOVA, N.V. and GOLOVLEVA, L.A. (2008). New efficient producers of fungal lacasses. Applied Biochemistry and Microbiology, vol. 44, no. 1, p. 73-77.

NICHKOVA, M.; GALVE, R. and MARCO, M.-P. (2002). Biological monitoring of 2,4,5-trichlorophenol (I): Preparation of antibodies and development of an immunoassay using theoretical models. Chemical Research Toxicology, vol. 15, no. 11, p. 1360-1370. [CrossRef]

NYANHONGO, G.S.; GOMES, J.; GÜBITZ, G.; ZVAUYA, R.; READ, J.S. and STEINER, W. (2002). Production of lacasse by a newly isolated strain of Trametes modesta. Bioresource Technology, vol. 84, no. 3, p. 259-263. [CrossRef]

PAICE, M.G.; JURASEK, L.; HO, C.; BOURBONNAIS, R. and ARCHIBALD, F. (1989). Direct biological bleaching of hardwood kraft pulp with the fungus Coriolus versicolor. Tappi Journal, vol. 72, no. 5, p. 217-221.

PALMIERI, G.; GIARDINA, P.; BIANCO, C.; FONTANELLA, B. and SANNIA, G. (2000). Copper induction of lacasse isoenzymes in the ligninolytic fungus Pleurotus ostreatus. Applied Environmental of Microbiology, vol. 66 , no. 3, p. $920-924$. 
PAPINUTTI, V.L.; DIORIO, L.A. and FORCHIASSIN, F. (2003). Production of lacasse and manganese peroxidase by Fomes sclerodermus grown on wheat bran. Journal of Industrial Microbiology and Biotechnology, vol. 30, no. 3, p. 157-160. [CrossRef]

RODRÍGUEZ COUTO, S.; GUNDÍN, M.; LORENZO, M. and SANROMÁN, M.A. (2002). Screening of supports and inducers for lacasse production by Trametes versicolor in semi-solid state conditions. Process Biochemistry, vol. 38, no. 2, p. 249-255. [CrossRef]

RODRÍGUEZ COUTO, S. and TOCA HERRERA, J.L. (2006). Industrial and biotechnological applications of lacasses: A review. Biotechnology Advances, vol. 24, no. 5, p. 500-513. [CrossRef]

RODRÍGUEZ, E.; NUERO, O.; GUILLÉN, F.; MARTÍNEZ, A.T. and MARTíNEZ, M.J. (2004). Degradation of phenolic and non-phenolic aromatic pollutants by four Pleurotus species: The role of lacasse and versatile peroxidase. Soil Biology \& Biochemistry, vol. 36, no. 6, p. 909-916. [CrossRef]

ROPER, J.C.; SARKAR, J.M.; DEC, J. and BOLLAG, J.-M. (1995). Enhanced enzymatic removal of chlorophenols in the presence of co-substrates. Water Research, vol. 29, no. 12, p. 2720-2724. [CrossRef]

ROSALES, E.; RODRIGUEZ COUTO, S. and SANROMÁN, A. (2002). New uses of food waste: Application to lacasse production by Trametes hirsuta. Biotechnology Letters, vol. 24, no. 9, p. 701-704. [CrossRef]

RUBILAR, O.; DIEZ, M.C. and GIANFREDA, L. (2008). Transformation of chlorinated phenolic compounds by white rot fungi. Critical Reviews in Environmental Science and Technology, vol. 38, no. 4, p. 227-268. [CrossRef]

SADHASIVAM, S.; SAVITHA, S.; SWAMINATHAN, K. and LIN, F.-H. (2008). Production, purification and characterization of mid-redox potential lacasse from a newly isolated Trichoderma harzianum WL1. Process Biochemistry, vol. 43, no. 7, p. 736-742. [CrossRef]

SAPARRAT, M.C.N.; GUILLÉN, F.; ARAMBARRI, A.M.; MARTÍNEZ, A.T. and MARTíNEZ, M.J. (2002). Induction, isolation, and characterization of two lacasses from the white rot basidiomycete Coriolopsis rigida. Applied and Environmental Microbiology, vol. 68, no. 4, p. 1534-1540. [CrossRef]

SCHLOSSER, D.; GREY, R. and FRITSCHE, W. (1997). Patterns of ligninolytic enzymes in Trametes versicolor. Distribution of extra- and intracellular enzyme activities during cultivation on glucose, wheat straw and beech wood. Applied Microbiology and Biotechnology, vol. 47, no. 4, p. 412-418. [CrossRef]

SCHULTZ, A.; JONAS, U.; HAMMER, E. and SCHAUER, F. (2001). Dehalogenation of chlorinated hydroxybiphenyls by fungal lacasse. Applied and Environmental Microbiology, vol. 67, no. 9, p. 4377-4381. [CrossRef]

SEDARATI, M.R.; KESHAVARZ, T.; LEONTIEVSKY, A.A. and EVANS, C.S. (2003). Transformation of high concentrations of chlorophenols by the white-rot basidiyomycete Trametes versicolor immobilized on nylon mesh. Electronic Journal of Biotechnology, vol. 6, no. 2, p. 104-114. [CrossRef]

SODEN, D.M. and DOBSON, A.D.W. (2001). Differential regulation of lacasse gene expression in Pleurotus sajorcaju. Microbiology, vol. 147, no. 7, p. 1755-1763.

STAZI, S.R.; FEVEREIRO, P.; SERMANNI, G.G. and BARROS, R.A. (2001). Oxidative polymerization and partial dechlorination of 2,4,6-trichlorophenol by a mixture of peroxidase isozymes from Vaccinium myrtillus. Journal of Chemical Technology \& Biotechnology, vol. 76, no. 2, p. 210-214. [CrossRef]

STEPANOVA, E.V.; PEGASOVA, T.V.; GAVRILOVA, V.P.; LANDESMAN, E.O. and KOROLEVA, O.V. (2003). Extracellular lacasses from Cerrena unicolor 059, Cerrena unicolor 0784, and Pleurotus ostreatus 0432: A comparative assay. Applied Biochemistry and Microbiology, vol. 39, no. 4, p. 375-381. [CrossRef]

THURSTON, C.F. (1994). The structure and function of fungal lacasses. Microbiology, vol. 140, no. 1, p. 19-26.

ÜNAL, A.T. and KOLANKAYA, N. (2001). Dechlorination of bleached kraft pulp by lacasse enzyme produced from some white-rot fungi. Turkish Journal of Biology, vol. 25, no. 1, p. 67-72.

ÜNAL, A.T. and KOLANKAYA, N. (2004). Chlorine removal from pp'DDT by lacasse enzyme produced from Trametes versicolor. Turkish Electronic Journal of Biotechnology, vol. 2, p. 17-21.

UNYAYAR, A.; DEMIRBILEK, M.; TURKOGLU, M.; CELIK, A; MAZMANCI, M.A.; ERKURT, E.A.; UNYAYAR, S.; CEKIC, O. and ATACAG, H. (2006). Evaluation of cytotoxic and mutagenic effects of Coriolus versicolor and Funalia trogii extracts on mammalian cells. Drug and Chemical Toxicology, vol. 29, no. 1, p. 69-83.

XAVIER, A.M.R.B.; TAVARES, A.P.M.; FERREIRA, R. and AMADO, F. (2007). Trametes versicolor growth and lacasse induction with by-products of pulp and paper industry. Electronic Journal of Biotechnology, vol. 10, no. 3, p. 444-451. [CrossRef]

\section{How to cite this article:}

GEDIKLI, S.; AYTAR, P.; ÜNAL, A.; YAMAÇ, M.; ÇABUK, A. and KOLANKAYA, N. (2010). Enhancement with inducers of lacasse production by some strains and application of enzyme to dechlorination of $2,4,5$ trichlorophenol. Electronic Journal of Biotechnology, vol. 13, no. 6. http://dx.doi.org/10.2225/vol13-issue6fulltext-9 